\title{
Endogenous Insulin-like Growth Factor (IGF) Binding Proteins Cause IGF-I Resistance in Cultured Fibroblasts from a Patient with Short Stature
}

\author{
Sherida E. Tollefsen, ${ }^{*}$ Ellen Heath-Monnig, ${ }^{\ddagger}$ Margaret A. Cascieri, ${ }^{\prime}$ Marvin L. Bayne, ${ }^{*}$ and William H. Daughaday \\ ${ }^{*}$ Edward Mallinckrodt Department of Pediatrics and the ${ }^{\ddagger}$ Department of Internal Medicine, Washington University \\ School of Medicine, St. Louis, Missouri 63110; and the \$Department of Biochemical Endocrinology, \\ Merck Sharp and Dohme Research Laboratories, Rahway, New Jersey 07065
}

\section{Abstract}

The ED $_{50}$ of insulin-like growth factor (IGF)-I-stimulated $\alpha$ aminoisobutyric acid (AIB) uptake (mean \pm SD) in cultured fibroblasts from a child with short stature that we have reported $(1.40 \pm 0.24 \mathrm{nM})$, is significantly higher than the $\mathrm{ED}_{50}$ of IGFI-stimulated AIB uptake in fibroblasts from 11 normal subjects $(0.42 \pm 0.12 \mathrm{nM})$ and from 127 short children $(0.35 \pm 0.11$ $\mathrm{nM})$. Similarly, the $\mathrm{ED}_{50}$ of IGF-I-stimulated thymidine incorporation in fibroblasts from this child is $\mathbf{2 . 8}$ times higher than that in fibroblasts from four normal subjects. To minimize potential modulation of IGF-I action by endogenous IGF binding proteins in these assays, fibroblast responsiveness to $\left[Q^{3}, A^{4}, Y^{15}, L^{16}\right] I G F-I$, an IGF-I variant that has a 600 -fold reduced affinity for serum IGF binding proteins, has been examined. The biological activity of this variant is comparable in the patient's and normal fibroblasts, suggesting that the resistance to IGF-I action cannot be attributed to a defective IGF-I receptor. To investigate directly the possibility that IGF-I sensitivity in the patient's fibroblasts is reduced by endogenous IGF binding proteins (IGFBP), binding proteins that are secreted into AIB assay buffer during a 3-h collection and that are cell-associated at the end of the collection have been analyzed. Ligand blot analysis of conditioned AIB assay buffer demonstrates that fibroblasts from the patient secrete 1.3-2.2 times more of $M_{r}$ $46,400 / 42,900,32,000$, and 26,800 binding proteins than normal fibroblasts. The major difference between fibroblasts from the patient and from normal subjects is a striking 10 -fold increase in the amount of a cell surface $M_{r} 32,000$ binding protein in the patient's fibroblasts. The $M, 32,000$ binding protein is similar in size to IGFBP-1 and different from IGFBP-2 and IGFBP-3, but it does not cross-react with an antibody against IGFBP-1. We conclude that the resistance to IGF-I action in the patient's fibroblasts is caused by an abnormal production and/or cell association of IGF binding proteins. (J. Clin. Invest. 1991. 87:1241-1250.) Key words: insulin-like growth factor $\bullet \alpha$-aminoisobutyric acid $\bullet$ effective dose

These studies were presented in part at the 72nd Annual Meeting of The Endocrine Society in Atlanta, GA, 1990 (Abstract 604).

Address correspondence to Dr. Sherida E. Tollefsen, Washington University School of Medicine, Department of Pediatrics, 400 South Kingshighway, St. Louis, MO 63110.

Received for publication 18 January 1990 and in revised form 15 November 1990

J. Clin. Invest.

(C) The American Society for Clinical Investigation, Inc.

$0021-9738 / 91 / 04 / 1241 / 10 \$ 2.00$

Volume 87, April 1991, 1241-1250

\section{Introduction}

Insulin-like growth factor I (IGF-I) ${ }^{1}$ is a major mammalian postnatal growth factor that plays a key role in mediating the growth effects of pituitary growth hormone (1). In responsive cells, IGF-I interacts at the plasma membrane with the IGF-I receptor, a heterotetrameric glycoprotein structurally homologous to the insulin receptor (2). IGF-I binding causes the transmembrane activation of the intrinsic tyrosine kinase activity of the IGF-I receptor. This results, by mechanisms that are not well understood, in rapid insulin-like effects on intermediary metabolism and more slowly developing effects on growth. The response to IGF-I in many tissues may be modulated by high affinity IGF binding proteins (IGFBPs), three of which have been well characterized and termed IGFBP-1,2, and 3 (3). Several cell types have been shown to produce IGF binding proteins, and these binding proteins may inhibit or enhance IGF-I action (reviewed in reference 4 ).

The sensitivity of target tissues to IGF-I may be an important determinant of growth. Bierich et al. (5) reported that fibroblasts from a short child with growth failure bound $50 \%$ less ${ }^{125}$ I-labeled IGF-I than normal fibroblasts, although the structure and function of the IGF-I receptor in this child's fibroblasts were not directly examined. We have investigated IGF-I sensitivity in cultured skin fibroblasts from patients with short stature and have reported that fibroblasts from one child were significantly less responsive to stimulation by IGF-I in $\alpha$-aminoisobutyric acid (AIB) uptake assays (6). The $\mathrm{ED}_{50} \mathrm{~S}$ of IGF-Istimulated AIB uptake (mean \pm SD) in fibroblasts from 11 normal subjects $(0.42 \pm 0.12 \mathrm{nM})$ and from 127 short children $(0.35 \pm 0.11 \mathrm{nM})$ are similar (Heath-Monnig, E., D. P. Dempsher, and W. H. Daughaday, unpublished results) and significantly lower than the $\mathrm{ED}_{\mathbf{5 0}}$ of IGF-I-stimulated AIB uptake in fibroblasts from this patient $(1.40 \pm 0.24 \mathrm{nM})$. IGF-I binding to the patient's fibroblasts suspended by brief treatment with trypsin appeared to be normal, although interpretation of these studies was complicated since treatment of the cells with trypsin could potentially modify the IGF-I receptor and would remove adherent binding proteins $(7,8)$.

In this study, we have used an IGF-I variant that interacts minimally with IGF binding proteins to examine fibroblast responsiveness. This variant, in which residues $3,4,15$, and 16 have been changed from $G^{3}, T^{4}, Q^{15}, F^{16}$ to $Q^{3}, A^{4}, Y^{15}, L^{16}$, has a 600 -fold reduced affinity for serum binding proteins but an affinity for the IGF-I receptor that is equal to that of IGF-I (9). The comparable biological activity of this IGF-I variant in nor-

1. Abbreviations used in this paper: AIB, $\alpha$-aminoisobutyric acid; CSC, child with short stature; IGF, insulin-like growth factor; IGFBP-1,2,3, IGF binding protein $1,2,3$. 
mal and the patient's fibroblasts suggested that the resistance to IGF-I action in the patient's fibroblasts could not be attributed to a defective IGF-I receptor. We report here that IGF-I sensitivity in this patient's fibroblasts is reduced by an abnormal production of IGF binding proteins.

\section{Methods}

Materials. AIB, Hepes, polyethylene glycol (PEG) 8000, BSA, bovine gamma-globulins, nitroblue tetrazolium, 5-bromo-4-chloro-3-indolyl phosphate, $N, N$-dimethylformamide, L-glutamine, and RPMI 1640 medium were purchased from Sigma Chemical Co., St. Louis, MO. Disuccinimidyl suberate was obtained from Pierce Chemical Co., Rockford, IL. Alkaline phosphatase-conjugated goat anti-rabbit IgG was supplied by Calbiochem-Behring Corp., San Diego, CA. $\alpha$ [Methyl- $\left.{ }^{3} \mathrm{H}\right]$-aminoisobutyric acid $\left(\left[{ }^{3} \mathrm{H}\right] \mathrm{AIB}\right), 33.5 \mathrm{Ci} / \mathrm{mmol}$, and [methyl- ${ }^{3} \mathrm{H}$ ] thymidine, $20 \mathrm{Ci} / \mathrm{mmol}$, were purchased from DuPont/ New England Nuclear Research Products, Boston, MA, and $\mathrm{Na}^{125} \mathrm{I}$, $13-17 \mathrm{mCi}^{125} \mathrm{I} / \mu \mathrm{g} \mathrm{I}$, was purchased from Amersham Corp., Arlington Heights, IL. FCS, DME, and MEM were routinely supplied by Gibco Laboratories, Grand Island, NY, and FCS was also obtained from J. R. Scientific, Inc., Woodland, CA. Tissue culture supplies were obtained from the following companies: $100-\mathrm{mm}$ culture plates from Corning Glass Works, Corning, NY, 150-mm culture plates from Falcon Plastics, Lincoln Park, NJ, and 24-well tissue culture clusters from Costar, Cambridge, MA. Nitrocellulose sheets were obtained from Schleicher and Schuell, Inc., Keene, NH.

Recombinant human $\left[\mathrm{T}^{59}\right]$ IGF-I was obtained from AmGen Biologicals, Thousand Oaks, CA, and was used as native IGF-I in these studies. $\left[\mathrm{Q}^{3}, \mathrm{~A}^{4}, \mathrm{Y}^{15}, \mathrm{~L}^{16}\right] \mathrm{IGF}-\mathrm{I}$ was prepared by site-directed mutagenesis of a synthetic gene as previously described (9). ${ }^{125}$ I-labeled IGF-I $(0.80-1.42 \mathrm{Ci} / \mu \mathrm{mol})$ and ${ }^{125} \mathrm{I}$-labeled $\left[\mathrm{Q}^{3}, \mathrm{~A}^{4}, \mathrm{Y}^{15}, \mathrm{~L}^{16}\right] \mathrm{IGF}-\mathrm{I}(0.78-1.22$ $\mathrm{Ci} / \mu \mathrm{mol})$ were prepared as previously described $(10)$.

Ascites fluid containing the MAb to the IGF-I receptor, $\alpha$ IR-3 (11), was kindly provided by Dr. Steven Jacobs (The Wellcome Research Laboratories, Research Triangle Park, NC). $\alpha$ IR-3 was affinity purified from the ascites fluid to remove IGF binding proteins using an EconoPac Protein A Kit, essentially as described by the manufacturer (BioRad Laboratories, Richmond, CA). Rabbit anti-human IGFBP-1 antibody, raised against purified amniotic fluid IGFBP-1, and rabbit antihuman IGFBP-3 antibody (12), were kindly provided by Dr. David Clemmons (University of North Carolina School of Medicine, Chapel Hill, NC) and by Dr. Robert Baxter (Royal Prince Alfred Hospital, Camperdown, NSW, Australia), respectively.

Cell culture. The following skin fibroblasts from three normal subjects were obtained from the Human Genetic Mutant Cell Repository, Coriell Institute of Medical Research, Camden, NJ: GM3349 from a 10-yr-old boy, GM5565 from a 3-yr-old boy, and GM5757 from a 7 -yr-old boy. Fibroblasts from two other normal subjects, an 18-yr-old man (WUMS1) and a 37-yr-old man (WUMS2), were isolated in our institution. Fibroblasts from the patient, which we have designated CSC, were obtained at 9.8 yr of age, because her serum IGF-I level was elevated/high normal when measured by two different methods. Clinical data on the patient (Patient 1) have been presented previously (6). From 13 to $15.5 \mathrm{yr}$ of age, the girl received recombinant human growth hormone $(0.3 \mathrm{mg} / \mathrm{kg} / \mathrm{wk})$. She achieved a final height of $156 \mathrm{~cm}$ (Dr. Hulda Wohltmann, Charleston, SC, personal communication).

Fibroblast stock cultures were maintained in DME containing antibiotics $(0.625 \mu \mathrm{g} / \mathrm{ml}$ amphotericin B, $100 \mu \mathrm{g} / \mathrm{ml}$ penicillin G, $100 \mu \mathrm{g} /$ $\mathrm{ml}$ streptomycin sulfate) and $15 \%$ FCS, as previously described (6). Experiments were performed on fibroblasts at passages 6-13, plated in DME containing antibiotics and 10\% FCS. All the cultures were fed 3-4 d after plating. The cells were studied at confluency 6-9 d after plating.

The human hepatoma cell line HepG2, which produces IGFBP-1 (13), and the human T helper cell line Jurkat, which produces IGFBP-2 (14), were obtained from Dr. Richard Ostlund and Dr. Dennis Loh, respectively, at this institution. HepG2 cells were maintained in MEM containing antibiotics, $4 \mathrm{mM}$ L-glutamine, and 10\% FCS. Jurkat cells were maintained in MEM with $25 \mathrm{mM}$ Hepes/RPMI 1640 medium (1:1) containing antibiotics, $2 \mathrm{mM}$ L-glutamine, and 10\% FCS

AIB uptake studies. AIB uptake assays were performed in 24-well clusters as previously described (6), using an assay volume of 250 or $500 \mu \mathrm{l}$ as indicated. Day 8 cell monolayers were used.

Thymidine incorporation studies. Thymidine incorporation assays were performed in 24-well clusters as described by Sasaoka et al. (15) with minor modifications. Briefly, day 8 cell monolayers were washed three times with Puck's Saline $G$ and then incubated with increasing amounts of IGF-I or $\left[\mathrm{Q}^{3}, \mathrm{~A}^{4}, \mathrm{Y}^{15}, \mathrm{~L}^{16}\right] \mathrm{IGF}-\mathrm{I}$ in serum-free medium (MEM with $25 \mathrm{mM}$ Hepes, $\mathrm{pH} 7.4$, antibiotics, and $1 \mathrm{mg} / \mathrm{ml} \mathrm{BSA}$ ) in a volume of $500 \mu \mathrm{l}$. After a $20-\mathrm{h}$ incubation at $37^{\circ} \mathrm{C}$ in room air, $\left[{ }^{3} \mathrm{H}\right]-$ thymidine (final concentration, $0.5 \mu \mathrm{Ci} / \mathrm{ml}$ ) was added for $4 \mathrm{~h}$. The cells were then washed with ice-cold Puck's Saline G three times, $10 \%$ TCA twice, 95\% ethanol/ether (3:1) twice, and air dried. TCA-precipitable material was dissolved in $500 \mu \mathrm{l}$ of $1 \% \mathrm{SDS}$, and a $200-\mu \mathrm{l}$ aliquot was counted in a Packard Tri-Carb 1500 liquid scintillation counter. The $\mathrm{ED}_{50}$ for IGF-I or $\left[\mathrm{Q}^{3}, \mathrm{~A}^{4}, \mathrm{Y}^{15}, \mathrm{~L}^{16}\right]$ IGF-I stimulation of thymidine incorporation was determined exactly as described for AIB uptake (6).

IGF-I binding to fibroblast monolayers. IGF-I binding studies were performed in 24-well clusters as previously described (16). Briefly, day 9 cell monolayers were incubated at $4^{\circ} \mathrm{C}$ with ${ }^{125}$ I-labeled IGF-I or ${ }^{125}$ I-labeled $\left[\mathrm{Q}^{3}, \mathrm{~A}^{4}, \mathrm{Y}^{15}, \mathrm{~L}^{16}\right] \mathrm{IGF}-\mathrm{I}$ and either increasing amounts of unlabeled ligand or $2.3 \mu \mathrm{g} / \mathrm{ml} \alpha \mathrm{IR}-3$ in serum-free medium. The final volume was $250 \mu \mathrm{l}$. After an 18-20-h incubation, the cells were washed three times and then solubilized in $1 \%$ SDS. An aliquot was counted in a Packard Auto-gamma 500C gamma counter. In preliminary experiments, we found that IGF-I and $\left[\mathrm{Q}^{3}, \mathrm{~A}^{4}, \mathrm{Y}^{15}, \mathrm{~L}^{16}\right] \mathrm{IGF}-\mathrm{I}$ binding to both normal and CSC fibroblasts reached a steady state at $18 \mathrm{~h}$. Cell counts were determined from replicate wells in each experiment.

Affinity cross-linking analysis. Day 6 or 8 cell monolayers were washed three times with serum-free DME separated by 20-min incubations at $37^{\circ} \mathrm{C}$, and affinity cross-linking analysis was performed as previously described (17).

Collection of fibroblast binding proteins. $0.5 \times 10^{6}$ cells were plated onto $100-\mathrm{mm}$ plates in $10 \mathrm{ml}$ DME containing antibiotics and $10 \%$ FCS in order to scale-up the incubation conditions used in the AIB uptake assay. Day 8 cell monolayers, untreated or pretreated for $2 \mathrm{~d}$ with serum-free medium at $37^{\circ} \mathrm{C}$ in room air, were used. The serumfree medium was collected, clarified by low speed centrifugation, and stored at $-20^{\circ} \mathrm{C}$ until assayed. The monolayers were washed three times with Krebs-Ringer phosphate buffer, $\mathrm{pH} 7.37$, with $5.5 \mathrm{mM}$ glucose. $6.55 \mathrm{ml}$ of AIB assay buffer (Krebs-Ringer phosphate buffer, pH 7.37 , with $5.5 \mathrm{mM}$ glucose and $1 \mathrm{mg} / \mathrm{ml} \mathrm{BSA}$ ) was then added (corresponding to a $250-\mu \mathrm{l}$ assay volume). After a $3 \mathrm{~h}$ incubation at $37^{\circ} \mathrm{C}$ in room air, the conditioned AIB assay buffer was removed, clarified by low speed centrifugation, and stored at $-20^{\circ} \mathrm{C}$ until assayed. The cells were washed three times with Puck's Saline $\mathrm{G}$ and were solubilized in $500 \mu \mathrm{l}$ of electrophoresis sample buffer $(62.5 \mathrm{mM}$ Tris- $\mathrm{HCl}, \mathrm{pH} 6.8,2 \%$ SDS, $10 \%$ glycerol, $0.001 \%$ bromophenol blue) without 2-mercaptoethanol. Cell counts were determined from replicate plates in each experiment.

Ligand and Western blotting. Aliquots of conditioned serum-free medium, conditioned AIB assay buffer, or solubilized cells were brought to $80 \mu \mathrm{l}$ with concentrated electrophoresis sample buffer (final concentration, $62.5 \mathrm{mM}$ Tris- $\mathrm{HCl}, \mathrm{pH} 6.8,2 \%$ SDS, $10 \%$ glycerol, $0.001 \%$ bromophenol blue) without 2 -mercaptoethanol and heated for $2 \mathrm{~min}$ at $100^{\circ} \mathrm{C}$. SDS-PAGE was performed according to the method of Laemmli (18) with $12.5 \%$ acrylamide resolving gels of $0.75 \mathrm{~mm}$ thickness, as described by Hossenlopp et al. (19). Prestained molecular weight standards (Bethesda Research Laboratories, Gaithersburg, MD) included myosin $\left(M_{r} 200,000\right)$, phosphorylase b $\left(M_{r} 97,400\right)$, BSA $\left(M_{r}\right.$ $68,000)$, ovalbumin $\left(M_{r} 43,000\right)$, carbonic anhydrase $\left(M_{r} 29,000\right)$, $\beta$-lactoglobulin $(M, 18,400)$, and lysozyme $(M, 14,300)$. Because coupling of the blue chromophore to these standards affects their electrophoretic behavior in SDS-PAGE, the molecular weights of the pre- 
stained standards empirically determined by the manufacturer were used to estimate the molecular weights of the IGF binding proteins. Proteins were electrophoretically transferred to nitrocellulose sheets according to the method of Towbin et al. (20). Transfer was accomplished in a GENIE electrophoretic blotter (Idea Scientific Company, Corvallis, OR) using a transfer buffer containing $25 \mathrm{mM}$ Tris, $\mathrm{pH} 8.3$, $192 \mathrm{mM}$ glycine, and $20 \%$ methanol and applying a current of $\sim 0.6$ Amp for $1 \mathrm{~h}$.

For ligand blot analysis, the blot was incubated overnight at room temperature in blocking buffer $(50 \mathrm{mM}$ Tris- $\mathrm{HCl}, \mathrm{pH} 7.8$, with $5 \%$ Carnation nonfat dry milk, $2 \mathrm{mM} \mathrm{CaCl}, 0.01 \%$ antifoam A emulsion, and $0.05 \%$ Triton $\mathrm{X}-100)$ with gentle shaking. ${ }^{125}$ I-labeled IGF-I $\left(10^{5}\right.$ $\mathrm{cpm} / \mathrm{ml}$ buffer) was then added for $2 \mathrm{~h}$. The blot was washed with fresh blocking buffer and then twice with PBS and dried. Autoradiographs were obtained by exposure of the dried blots to Kodak XAR-5 x-ray film in the presence of a Cronex Lightning Plus intensifying screen at $-70^{\circ} \mathrm{C}$ and were scanned with an LKB Ultrascan XL laser densitometer.

For Western blot analysis, the blot was washed and incubated overnight at room temperature in TBS $(50 \mathrm{mM}$ Tris- $\mathrm{HCl}, \mathrm{pH} 7.4,200 \mathrm{mM}$ $\mathrm{NaCl}$ ) with $30 \mathrm{mg} / \mathrm{ml} \mathrm{BSA}$ and $0.02 \% \mathrm{NaN}_{3}$. Rabbit anti-human IGFBP-1 antibody (1:10,000 dilution) in TBS with $10 \mathrm{mg} / \mathrm{ml} \mathrm{BSA}$ was then added for $1.5 \mathrm{~h}$. The blots were washed three times with TBS containing $0.1 \%$ NP- 40 and $0.03 \%$ Triton X-100, once with TBS, and then incubated for $2 \mathrm{~h}$ with alkaline phosphatase-conjugated goat anti-rabbit IgG (1:5,000 dilution) in TBS with $10 \mathrm{mg} / \mathrm{ml}$ BSA. The blots were washed as described above, washed once with AP buffer ( 100 $\mathrm{mM}$ Tris- $\mathrm{HCl}$, pH 9.5, with $100 \mathrm{mM} \mathrm{NaCl}$, and $5 \mathrm{mM} \mathrm{MgCl}$ ), and developed using $66 \mu \mathrm{l}$ of nitroblue tetrazolium $(50 \mathrm{mg} / \mathrm{ml}$ in $70 \%$ $N, N$-dimethylformamide) and $33 \mu 1$ of 5-bromo-4-chloro-3-indolyl phosphate $(50 \mathrm{mg} / \mathrm{ml}$ in $100 \% N, N$-dimethylformamide) in $10 \mathrm{ml} \mathrm{AP}$ buffer. After $30 \mathrm{~min}$, the blot was washed with PBS with $20 \mathrm{mM}$ EDTA and dried.

IGF binding protein binding studies. IGF-I binding to secreted IGF binding proteins was determined as described by McCusker and Clemmons (21). Briefly, conditioned AIB assay buffer was incubated with ${ }^{125}$ I-labeled IGF-I and increasing amounts of unlabeled IGF-I in $0.1 \mathrm{M}$ Hepes, $\mathrm{pH} 6.0$, with $44 \mathrm{mM} \mathrm{NaH}_{2} \mathrm{PO}_{4}, 0.01 \%$ Triton X-100, $1 \mathrm{mg} / \mathrm{ml}$ $\mathrm{BSA}$, and $0.02 \% \mathrm{NaN}_{3}$ in $1.5 \mathrm{ml}$ microfuge tubes. The final volume was $250 \mu$ l. After a $1-\mathrm{h}$ incubation at room temperature, complexes of binding protein and IGF-I were precipitated at $4^{\circ} \mathrm{C}$ by the addition of $250 \mu \mathrm{l}$ of $0.4 \%$ bovine gamma-globulins in $0.1 \mathrm{M}$ Tris- $\mathrm{HCl}, \mathrm{pH} 7.4$, and $500 \mu \mathrm{l}$ of $25 \%$ PEG, followed by centrifugation in an Eppendorf microfuge for $15 \mathrm{~min}$. The supernatant fluid was removed by aspiration, and the lower tip of the tube, containing the pellet, was excised and counted in a Micromedic 4/200 Automatic gamma counter. ${ }^{125}$ I-labeled IGF-I binding was dependent on the amount of conditioned AIB assay buffer in the assay, and experimental results presented in this study were those obtained using amounts of conditioned AIB assay buffer at which the dose-dependent relationship was linear.

Methods of analysis. The data from competition binding studies were analyzed by LIGAND, a computer program developed by Munson and Rodbard (22). The values reported for binding capacities and dissociation constants were obtained from a fit based on one class of sites since the improvement in fit by adding another class of sites was not substantial enough to warrant the additional complexity.

\section{Results}

IGF-I stimulation of AIB uptake and thymidine incorporation in normal and CSC fibroblasts. We have reported that fibroblasts from a child with short stature (CSC) were significantly less responsive to stimulation by IGF-I than fibroblasts from normal subjects (6). Fig. 1 shows a representative experiment in which the $\mathrm{ED}_{50}$ of IGF-I-stimulated AIB uptake in this patient's fibroblasts was three times higher than that in normal fibroblasts. In order to minimize potential modulation of IGF-

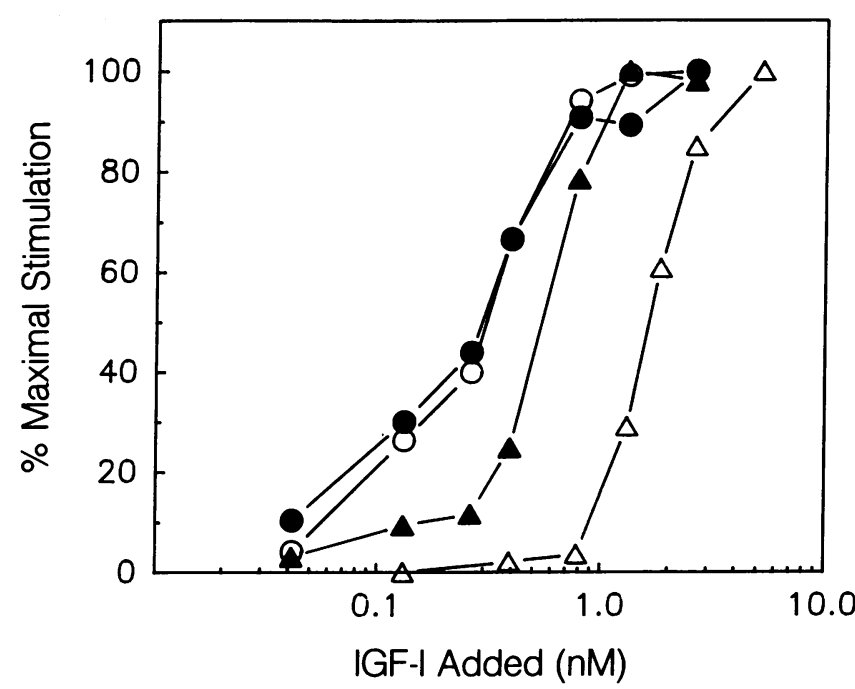

Figure 1. IGF-I and $\left[\mathrm{Q}^{3}, \mathrm{~A}^{4}, \mathrm{Y}^{15}, \mathrm{~L}^{16}\right]$ IGF-I stimulation of AIB uptake in normal and CSC fibroblasts. GM5565 $(\Delta, \bullet)$ and $\operatorname{CSC}(\Delta, 0)$ fibroblasts were incubated with increasing amounts of IGF-I $(\Delta, \Delta)$ or $\left[\mathrm{Q}^{3}, \mathrm{~A}^{4}, \mathrm{Y}^{15}, \mathrm{~L}^{16}\right] \mathrm{IGF}-\mathrm{I}(\bullet, \mathrm{O})$ for $3 \mathrm{~h}$ in a volume of $500 \mu \mathrm{l}$. Uptake of $30 \mu \mathrm{M}$ AIB containing $\left.2 \mu \mathrm{Ci} / \mathrm{ml}^{3} \mathrm{H}\right]$ AIB in $20 \mathrm{~min}$ was then measured, as previously described (6). Each point represents the mean of triplicate determinations. The data are presented as the percent of maximal stimulation observed for each dose-response curve. The $E_{50}$ for IGF-I stimulation of AIB uptake in GM5565 and CSC fibroblasts were $0.54 \mathrm{nM}$ and $1.63 \mathrm{nM}$, respectively, and for $\left[\mathrm{Q}^{3}, \mathrm{~A}^{4}, \mathrm{Y}^{15}, \mathrm{~L}^{16}\right] \mathrm{IGF}-\mathrm{I}$ stimulation were $0.29 \mathrm{nM}$ and $0.31 \mathrm{nM}$, respectively.

I action by endogenous IGF binding proteins in these assays, we examined fibroblast responsiveness to $\left[\mathrm{Q}^{3}, \mathrm{~A}^{4}, \mathrm{Y}^{15}, \mathrm{~L}^{16}\right] \mathrm{IGF}$ I, an IGF-I variant that has a reduced affinity for human serum IGF binding proteins (9). As shown in Fig. 1, AIB uptake in normal and CSC fibroblasts was comparably stimulated by $\left[Q^{3}, A^{4}, Y^{15}, L^{16}\right]$ IGF-I. Table I summarizes IGF-I and $\left[\mathrm{Q}^{3}, \mathrm{~A}^{4}, \mathrm{Y}^{15}, \mathrm{~L}^{16}\right]$ IGF-I stimulation of AIB uptake in fibroblasts from the patient and from five normal subjects. The $\mathrm{ED}_{50} \mathrm{~s}$ of $\left[\mathrm{Q}^{3}, \mathrm{~A}^{4}, \mathrm{Y}^{15}, \mathrm{~L}^{16}\right] \mathrm{IGF}-\mathrm{I}-\mathrm{stimulated} \mathrm{AIB}$ uptake in CSC $(0.38$ $\mathrm{nM})$ and normal $(0.27 \mathrm{nM})$ fibroblasts were very similar. Furthermore, the mean $\mathrm{ED}_{50}$ of $\left[\mathrm{Q}^{3}, \mathrm{~A}^{4}, \mathrm{Y}^{15}, \mathrm{~L}^{16}\right] \mathrm{IGF}-\mathrm{I}$-stimulated AIB uptake was $39.7 \%$ and $20.0 \%$ of that of IGF-I-stimulated AIB uptake in normal and CSC fibroblasts, respectively. Maximal stimulation of AIB uptake (mean \pm SE) by IGF-I (2.3 \pm 0.1 -fold in five normal and $2.1 \pm 0.1$-fold in CSC fibroblasts) and by $\left[\mathrm{Q}^{3}, \mathrm{~A}^{4}, \mathrm{Y}^{15}, \mathrm{~L}^{16}\right] \mathrm{IGF}-\mathrm{I}(2.4 \pm 0.1$-fold in five normal and 2.5 \pm 0.1 -fold in CSC fibroblasts) did not differ significantly in these studies.

Table I also summarizes IGF-I and $\left[\mathrm{Q}^{3}, \mathrm{~A}^{4}, \mathrm{Y}^{15}, \mathrm{~L}^{16}\right] \mathrm{IGF}-\mathrm{I}$ stimulation of thymidine incorporation into DNA in fibroblasts from the patient and from four normal subjects. The mean $\mathrm{ED}_{50}$ of IGF-I-stimulated thymidine incorporation in the patient's fibroblasts was 2.8 times higher than that in normal fibroblasts. The $\mathrm{ED}_{50} \mathrm{~s}$ of $\left[\mathrm{Q}^{3}, \mathrm{~A}^{4}, \mathrm{Y}^{15}, \mathrm{~L}^{16}\right] \mathrm{IGF}-\mathrm{I}-\mathrm{stimulated}$ thymidine incorporation in CSC $(0.09 \mathrm{nM})$ and in normal $(0.12 \mathrm{nM})$ fibroblasts were very similar. Furthermore, the mean $\mathrm{ED}_{50}$ of $\left[\mathrm{Q}^{3}, \mathrm{~A}^{4}, \mathrm{Y}^{15}, \mathrm{~L}^{16}\right] \mathrm{IGF}-\mathrm{I}-\mathrm{stimulated}$ thymidine incorporation was $7.4 \%$ and $2.0 \%$ of that of IGF-I-stimulated thymidine incorporation in normal and CSC fibroblasts, respectively. Maximal stimulation of thymidine incorporation 


\begin{tabular}{|c|c|c|c|c|}
\hline & \multicolumn{2}{|c|}{ Stimulation of AIB Uptake $\left(E D_{s 0}\right)$} & \multicolumn{2}{|c|}{ Stimulation of Thymidine Incorporation $\left(\mathrm{ED}_{\mathrm{so}}\right)$} \\
\hline & IGF-I & {$\left[Q^{3}, A^{4}, Y^{15}, L^{16}\right] I G F-I$} & IGF-I & {$\left[Q^{3}, A^{4}, Y^{15}, L^{16}\right] I G F-$} \\
\hline & \multicolumn{2}{|c|}{$n M$} & \multicolumn{2}{|c|}{$n M$} \\
\hline \multicolumn{5}{|l|}{ Normals } \\
\hline GM5565 & $0.70 \pm 0.08$ & $0.22 \pm 0.01(3)$ & $1.98 \pm 0.29(6)$ & $0.03 \pm 0.01(6)$ \\
\hline GM3349 & $0.83 \pm 0.09(3)$ & $0.38 \pm 0.03(3)$ & $1.98 \pm 0.26(4)$ & $0.14 \pm 0.03(2)$ \\
\hline GM5757 & $0.94 \pm 0.24(3)$ & $0.19 \pm 0.02(3)$ & - & - \\
\hline WUMS1 & $0.40 \pm 0.05(3)$ & $0.29 \pm 0.05(3)$ & $0.98 \pm 0.16(6)$ & $0.15 \pm 0.02(3)$ \\
\hline WUMS2 & $0.53 \pm 0.06(3)$ & $0.27 \pm 0.01$ & $1.57 \pm 0.16(5)$ & $0.16 \pm 0.03(3)$ \\
\hline Mean \pm SD & $0.68 \pm 0.22$ & $0.27 \pm 0.07$ & $1.63 \pm 0.47$ & $0.12 \pm 0.06$ \\
\hline Patient (CSC) & $1.90 \pm 0.30(3)$ & $0.38 \pm 0.03(3)$ & $4.52 \pm 0.38(5)$ & $0.09 \pm 0.03(6)$ \\
\hline
\end{tabular}

IGF-I and $\left[Q^{3}, \mathrm{~A}^{4}, \mathrm{Y}^{15}, \mathrm{~L}^{16}\right] \mathrm{IGF}-\mathrm{I}$ stimulation of AIB uptake in fibroblasts from the patient and from five normal subjects were measured as described in the legend to Fig. 1 , using a $250-\mu l$ assay volume. IGF-I and $\left[Q^{3}, A^{4}, Y^{15}, L^{16}\right] I G F-I$ stimulation of thymidine incorporation in these fibroblasts were measured as described in Methods. The data are expressed as the $\mathrm{ED}_{50}$ of IGF-I or $\left[\mathrm{Q}^{3}, \mathrm{~A}^{4}, \mathrm{Y}^{15}, \mathrm{~L}^{16}\right] \mathrm{IGF}-\mathrm{I}-\mathrm{stimulated} \mathrm{AIB}$ uptake ${ }^{2}$ or thymidine incorporation (mean $\pm \mathrm{SE}$ ). The number of independently performed experiments is shown in parentheses.

(mean \pm SE) by IGF-I $(2.5 \pm 0.3$-fold in four normal and $2.5 \pm 0.2$-fold in CSC fibroblasts) and by $\left[\mathrm{Q}^{3}, \mathrm{~A}^{4}, \mathrm{Y}^{15}, \mathrm{~L}^{16}\right] \mathrm{IGF}-\mathrm{I}$ (2.6 \pm 0.3 -fold in four normal and 2.6 \pm 0.1 -fold in CSC fibroblasts) did not differ significantly in these studies.

Analysis of the IGF-I receptor in normal and CSC fibroblasts. Although we and others (6-8, 23-25) have studied IGFI binding to fibroblasts after brief treatment with trypsin to remove adherent binding proteins, potential modification of the IGF-I receptor by this treatment may complicate the interpretation of such studies. To compare IGF-I binding to the cell surface of normal and CSC fibroblast monolayers, competition binding studies were performed using IGF-I and $\left[Q^{3}, A^{4}, Y^{15}, L^{16}\right]$ IGF-I. Fig. 2 (left panels) shows Scatchard plots of data from a representative experiment. Scatchard plots of IGF-I and $\left[\mathrm{Q}^{3}, \mathrm{~A}^{4}, \mathrm{Y}^{15}, \mathrm{~L}^{16}\right]$ IGF-I binding to normal and CSC fibroblast monolayers were linear. In the experiment shown in Fig. $2 A$, normal fibroblasts bound $13.4 \mathrm{fmol}$ of IGF-I per well and CSC fibroblasts bound $58.8 \mathrm{fmol}$ of IGF-I per well. In five experiments, the IGF-I binding capacity (mean \pm SE) of CSC fibroblasts $(146,600 \pm 23,000$ sites/cell) was 2.9 times higher than that of normal (GM5565) fibroblasts $(49,900 \pm 10,000$ sites/cell). In contrast, as shown in Fig. $2 B,\left[\mathrm{Q}^{3}, \mathrm{~A}^{4}, \mathrm{Y}^{15}, \mathrm{~L}^{16}\right]$ IGF-I binding to normal and CSC fibroblast monolayers was similar. We have compared $\left[\mathrm{Q}^{3}, \mathrm{~A}^{4}, \mathrm{Y}^{15}, \mathrm{~L}^{16}\right] \mathrm{IGF}-\mathrm{I}$ binding to fibroblasts from the patient and from five normal subjects. In four experiments, the $\left[Q^{3}, A^{4}, Y^{15}, L^{16}\right]$ IGF-I binding capacity (mean \pm SD) of CSC fibroblasts $(13,600 \pm 4,400$ sites/cell) did not differ from that of five normal fibroblasts $(13,900 \pm 2,500$ sites/cell). The dissociation constants of $\left[Q^{3}, A^{4}, Y^{15}, L^{16}\right] I G F-I$ binding to CSC and normal fibroblasts were $0.39 \mathrm{nM}$ and $0.36-0.50 \mathrm{nM}$, respectively, indicating that the receptors have a similar affinity for $\left[Q^{3}, A^{4}, Y^{15}, L^{16}\right]$ IGF-I.

$\alpha \mathrm{IR}-3$, the MAb to the IGF-I receptor, has been shown to block IGF-I binding to human placental membranes, to human circulating monocytes, and to suspended human fibroblasts $(26,27)$. Inhibition of IGF-I and $\left[\mathrm{Q}^{3}, \mathrm{~A}^{4}, \mathrm{Y}^{15}, \mathrm{~L}^{16}\right] \mathrm{IGF}-\mathrm{I}$ binding to fibroblast monolayers by $\alpha$ IR-3 is shown in Fig. 2 (right panels). Initial experiments indicated that $2.3 \mu \mathrm{g} / \mathrm{ml}$ $\alpha$ IR-3 maximally inhibited ${ }^{125} \mathrm{I}$-labeled IGF-I and ${ }^{125} \mathrm{I}$-labeled $\left[\mathrm{Q}^{3}, \mathrm{~A}^{4}, \mathrm{Y}^{15}, \mathrm{~L}^{16}\right] \mathrm{IGF}-\mathrm{I}$ binding to normal fibroblast monolayers.
${ }^{125}$ I-labeled IGF-I binding to normal and CSC fibroblasts was inhibited $55 \%$ and $19 \%$, respectively, by $2.3 \mu \mathrm{g} / \mathrm{ml} \alpha \mathrm{IR}-3$, as shown in Fig. $2 A$. In contrast, ${ }^{125} \mathrm{I}$-labeled $\left[\mathrm{Q}^{3}, \mathrm{~A}^{4}, \mathrm{Y}^{15}, \mathrm{~L}^{16}\right] \mathrm{IGF}-\mathrm{I}$ binding to normal and CSC fibroblasts was inhibited $93 \%$ and $88 \%$, respectively, by $\alpha$ IR-3, as shown in Fig. $2 \mathrm{~B}$. Similar results were obtained in four other normal cell lines (data not shown).

The receptor to which IGF-I binds in these fibroblasts was determined by affinity cross-linking studies, as shown in Fig. 3 . ${ }^{125}$ I-labeled IGF-I was cross-linked predominantly to proteins that migrated under nonreducing conditions as complexes with apparent $M_{r}>300,000$. These proteins correspond to the $(\alpha \beta)_{2}$, the $(\alpha \beta)\left(\alpha \beta^{\prime}\right)$, and the $\left(\alpha \beta^{\prime}\right)_{2}$ forms of the IGF-I receptor (28). After reduction with 2-mercaptoethanol, these complexes migrated with an apparent $M_{r} 135,000$ (see Fig. 7 B). Crosslinking of ${ }^{125}$ I-labeled IGF-I was markedly inhibited by unlabeled IGF-I, was inhibited by unlabeled IGF-II, and was not inhibited by unlabeled insulin. Normal and CSC fibroblasts exhibited no qualitative or quantitative differences in IGF-I receptor cross-linking. Taken together with the normal responsiveness of CSC fibroblasts to $\left[\mathrm{Q}^{3}, \mathrm{~A}^{4}, \mathrm{Y}^{15}, \mathrm{~L}^{16}\right] \mathrm{IGF}-\mathrm{I}$, these studies indicate that the resistance to IGF-I action in the patient's fibroblasts is not caused by a defective IGF-I receptor.

Analysis of IGF binding proteins in normal and CSC fibroblasts. Since $\left[\mathrm{Q}^{3}, \mathrm{~A}^{4}, \mathrm{Y}^{15}, \mathrm{~L}^{16}\right] \mathrm{IGF}-\mathrm{I}$ interacts minimally with IGF binding proteins, the comparable stimulation of AIB uptake and thymidine incorporation by and binding of $\left[\mathrm{Q}^{3}, \mathrm{~A}^{4}, \mathrm{Y}^{15}, \mathrm{~L}^{16}\right] \mathrm{IGF}-\mathrm{I}$ in normal and CSC fibroblasts suggested that IGF-I sensitivity in the patient's fibroblasts was reduced by IGF binding proteins. To examine IGF binding proteins in normal and CSC fibroblasts directly, fibroblast binding proteins were collected and analyzed as described in Methods. Fig. 4 shows the ligand blot of binding proteins secreted into serum-

2. We have noted a small, but reproducible, increase in $\mathrm{ED}_{50} \mathrm{~S}$ of IGF-Istimulated AIB uptake when a volume of $250 \mu \mathrm{l}$ is used in the AIB uptake assay. Compare $\mathrm{ED}_{50} \mathrm{~s}$ in this table to those obtained in fibroblasts from 11 normal subjects $(0.42 \pm 0.12 \mathrm{nM})$, from 127 short children $(0.35 \pm 0.11 \mathrm{nM})$, and from the patient $(1.40 \pm 0.24 \mathrm{nM})$, using a $500-\mu l$ assay volume. 
A $\mid G F-1$
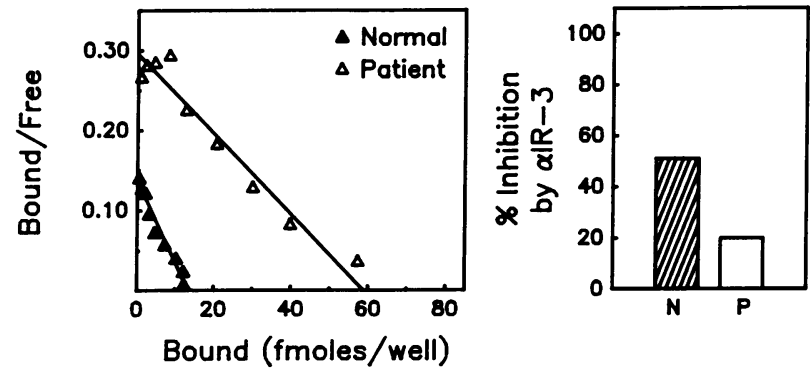

$\left[\mathrm{Gln}^{3}, \mathrm{Ala}^{4}, \mathrm{Tyr}^{15}\right.$, Leu $\left.^{16}\right] \mathrm{IGF}-1$
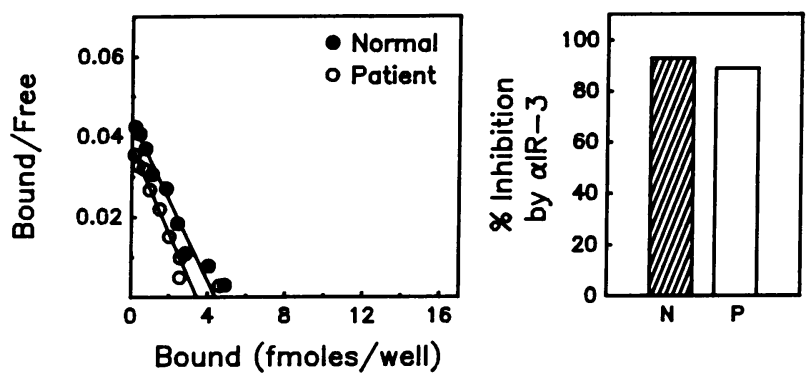

Figure 2. IGF-I and $\left[\mathrm{Q}^{3}, \mathrm{~A}^{4}, \mathrm{Y}^{15}, \mathrm{~L}^{16}\right] \mathrm{IGF}-\mathrm{I}$ binding to normal and CSC fibroblast monolayers. ( $A$ and $B$, left) Scatchard plots of IGF-I and $\left[Q^{3}, A^{4}, Y^{15}, L^{16}\right]$ IGF-I binding. Competition binding studies were performed at $4^{\circ} \mathrm{C}$ as described in Methods, using GM5565 $\left(1.9 \times 10^{5}\right.$ cells/well) or CSC $\left(1.8 \times 10^{5}\right.$ cells/well $)$ fibroblast monolayers. Binding assays contained $7,300 \mathrm{cpm}(0.02 \mathrm{nM})$ of ${ }^{125}$ I-labeled IGF-I $(A)$ or $7,900 \mathrm{cpm}(0.02 \mathrm{nM})$ of ${ }^{125}$ I-labeled $\left[\mathrm{Q}^{3}, \mathrm{~A}^{4}, \mathrm{Y}^{15}, \mathrm{~L}^{16}\right] \mathrm{IGF}-\mathrm{I}(B)$ and $0-6.54 \mathrm{nM}$ of unlabeled IGF-I $(A)$ or $\left[\mathrm{Q}^{3}, \mathrm{~A}^{4}, \mathrm{Y}^{15}, \mathrm{~L}^{16}\right] \mathrm{IGF}-\mathrm{I}(B)$ in a final volume of $250 \mu \mathrm{l}$. Each point represents the mean of duplicate determinations. Binding data were analyzed by LIGAND (22). $N$, the ratio of nonspecifically bound ligand to free ligand, was 0.009 and 0.010 in $A$ and 0.004 and 0.006 in $B$ for GM5565 and CSC fibroblasts, respectively. Nonspecific binding, $N \times F$, has been subtracted. The solid lines are computer-generated fits for a one-site binding model. In this experiment, the dissociation constants for IGF-I and $\left[\mathrm{Q}^{3}, \mathrm{~A}^{4}, \mathrm{Y}^{15}, \mathrm{~L}^{16}\right] \mathrm{IGF}-\mathrm{I}$ binding to $\mathrm{GM} 5565$ fibroblasts were $0.39 \mathrm{nM}$ and $0.40 \mathrm{nM}$ and to CSC fibroblasts were $0.80 \mathrm{nM}$ and $0.37 \mathrm{nM}$, respectively. ( $A$ and $B$, right) Inhibition of IGF-I and $\left[\mathrm{Q}^{3}, \mathrm{~A}^{4}, \mathrm{Y}^{15}, \mathrm{~L}^{16}\right] \mathrm{IGF}-\mathrm{I}$ binding by $\alpha \mathrm{IR}-3$. Binding of ${ }^{125}$ I-labeled IGF-I $(A)$ or ${ }^{125} \mathrm{I}$-labeled $\left[\mathrm{Q}^{3}, \mathrm{~A}^{4}, \mathrm{Y}^{15}, \mathrm{~L}^{16}\right] \mathrm{IGF}-\mathrm{I}(B)$ to GM5565 (cross-hatched bars) and CSC (open bars) fibroblast monolayers was measured in the absence and presence of $2.3 \mu \mathrm{g} / \mathrm{ml} \alpha \mathrm{IR}-3$. In the absence of $\alpha \mathrm{IR}-3$ $11.6 \%$ and $17.0 \%$ of ${ }^{125} \mathrm{I}$-labeled IGF-I and $4.7 \%$ and $4.8 \%$ of ${ }^{125} \mathrm{I}$-labeled $\left[\mathrm{Q}^{3}, \mathrm{~A}^{4}, \mathrm{Y}^{15}, \mathrm{~L}^{16}\right] \mathrm{IGF}-\mathrm{I}$ was specifically bound to GM5565 and CSC fibroblasts, respectively. Data are presented as the percent of total binding inhibited by $\alpha$ IR-3 (mean of two independently performed experiments).

free medium over $2 \mathrm{~d}$. The most prominent proteins in conditioned serum-free medium from both normal and CSC fibroblasts migrated on SDS-PAGE with apparent $M_{r}, 46,400$ and 42,900 . These appear to be identical in size to the major doublet of IGF binding proteins in human serum. In serum, a growth hormone-dependent $M_{r} 150,000$ complex (29) that dissociates upon acidification to yield free IGFs and an acid-stable subunit, termed IGFBP-3, contains most of the circulating IGFs. Martin and Baxter (30) showed, and we have confirmed

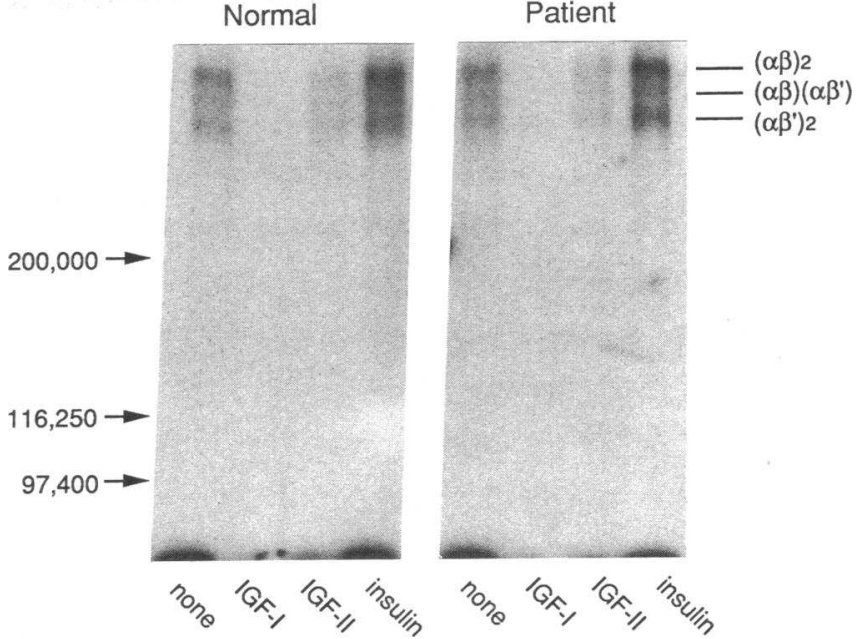

Figure 3. Affinity cross-linking analysis of the IGF-I receptor in normal and CSC fibroblasts. Day 6 GM5565 and CSC fibroblasts were incubated for $4 \mathrm{~h}$ at $15^{\circ} \mathrm{C}$ with $0.2 \mathrm{nM}{ }^{125} \mathrm{I}$-labeled IGF-I in the absence or presence of $100 \mathrm{ng} / \mathrm{ml}$ of unlabeled IGF-I, unlabeled IGFII, or unlabeled insulin, as indicated. Affinity cross-linking with 0.1 $\mathrm{mM}$ disuccinimidyl suberate was performed as previously described (17). The autoradiograph of the radioligand/receptor complexes, analyzed by SDS-PAGE ( $5 \%$ acrylamide resolving gel) under nonreducing conditions, is shown. The migration of molecular weight standards is indicated.

(data not shown), that the doublet in fibroblast-conditioned serum-free medium reacts with an antibody raised against human IGFBP-3. Two other proteins with apparent $M_{r} 32,000$ and 26,800 were also present in conditioned serum-free medium from both normal and CSC fibroblasts. ${ }^{3}$ All of these IGF binding proteins appeared to be secreted in increased amounts by CSC fibroblasts. To examine the possibility that the serumfree medium was contaminated by binding proteins from FCS in which the cells had been grown, we analyzed DME containing $10 \%$ FCS. The electrophoretic profile of IGF binding proteins in FCS was markedly different than that in conditioned serum-free medium. The major protein in FCS (apparent $M_{r}$ 36,800 ) did not appear to be present in the conditioned serumfree medium from fibroblasts.

To examine binding protein production during the AIB uptake assay, incubation conditions were scaled-up as described in Methods. IGF binding proteins secreted by normal and CSC fibroblasts were first compared in competition bind-

3. The electrophoretic profiles of IGF binding proteins secreted by fibroblasts into serum-free medium are very similar to those published recently by Conover et al. (31) and Hill et al. (32), although the estimated molecular weights of the binding proteins differ. It is likely that the binding proteins with apparent $M_{r} 46,400,42,900,32,000$, and 26,800 in our study correspond to those with apparent $M_{r} 41,500-42,000$, $37,000-39,000,28,000-30,000$, and $23,000-25,000$, respectively, in their studies. The differences reported in apparent molecular weights may result from the conditions of SDS-PAGE (a 12.5\% acrylamide resolving gel used in our study and a 5-15\% gradient acrylamide resolving gel employed in the study of Conover et al. [31]). In addition, we have used the plot of mobility vs. the logarithm of the molecular weights of the prestained standards empirically determined by the manufacturer rather than the logarithm of the reported molecular weights to estimate the molecular weights of the IGF binding proteins. 


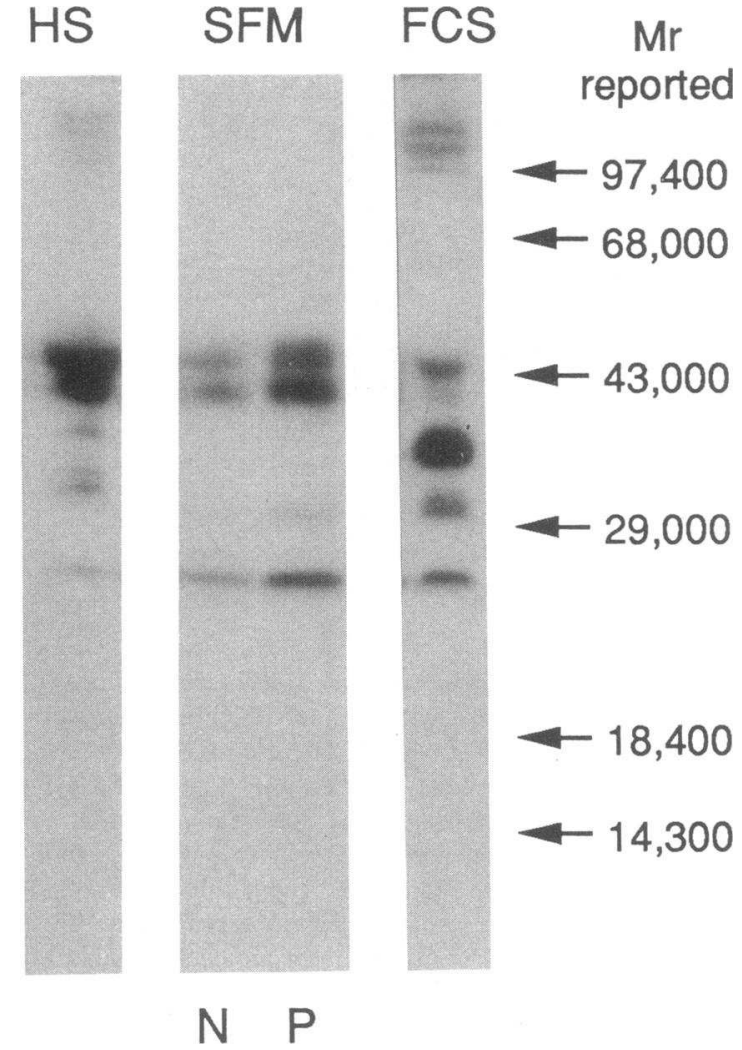

Figure 4. Ligand blot analysis of IGF binding proteins secreted by normal and CSC fibroblasts. GM5565 $(N)$ and CSC $(P)$ fibroblasts were treated for $2 \mathrm{~d}$ with serum-free medium. The conditioned serum-free medium (SFM) was collected, and 20- $\mu$ l aliquots were analyzed by ligand blotting, as described in Methods. A 1.6- $\mu \mathrm{l}$ aliquot of human serum $(H S)$ and a 20- $\mu$ l aliquot of DME containing $10 \%$ FCS were also analyzed. The migration of prestained molecular weight standards is indicated.

ing studies. Fig. 5 shows Scatchard plots of data from a representative experiment. Scatchard plots of IGF-I binding to 3-h conditioned AIB assay buffer from normal and CSC fibroblasts were linear. In this experiment, the binding capacities of conditioned AIB assay buffer from normal and CSC fibroblasts were $0.24 \mathrm{pmol}$ of IGF-I bound/ml and $0.49 \mathrm{pmol}$ of IGF-I bound/ $\mathrm{ml}$, respectively. Analysis of IGF-I binding to conditioned AIB assay buffer from three separate collections indicated that the IGF-I binding capacity of conditioned AIB assay buffer from CSC fibroblasts was 2.0-2.7 times higher than that from normal fibroblasts. ${ }^{4}$ The dissociation constants (mean \pm SD) of

4. The difference in binding capacity of conditioned AIB assay buffer from normal (GM5565) and CSC fibroblasts obtained from Scatchard plots, as shown in Fig. 5, was comparable to that obtained from binding of ${ }^{125}$ I-labeled IGF-I only (2.4 times). In a separate experiment, we compared binding of ${ }^{125}$ I-labeled IGF-I only to conditioned AIB assay buffer from fibroblasts from the patient and from five normal subjects (including GM5565). Conditioned AIB assay buffer from CSC fibroblasts bound 1.3-2.9 times more ${ }^{125}$ I-labeled IGF-I. When corrected for cell counts, conditioned AIB assay buffer from CSC fibroblasts bound 1.4-2.6 times more ${ }^{125}$ I-labeled IGF-I than that from four of five normal fibroblasts. Conditioned AIB assay buffer from WUMS2 fibroblasts bound as much ${ }^{125}$ I-labeled IGF-I as CSC fibroblasts when corrected for cell counts, despite its similarity to fibroblasts from the normal subjects in other assays (see Table I).
IGF-I binding to conditioned AIB assay buffer from normal and CSC fibroblasts were $0.056 \pm 0.006 \mathrm{nM}$ and $0.067 \pm 0.006$ $\mathrm{nM}$, respectively, indicating that the composite affinity of binding proteins secreted by normal and CSC fibroblasts for IGF-I is similar.

IGF binding proteins that were secreted into AIB assay buffer during a 3-h collection and that were cell-associated at the end of the collection were then analyzed by ligand blotting. As shown in Fig. 6, the electrophoretic profile of IGF binding proteins secreted into AIB assay buffer in $3 \mathrm{~h}$ was similar to that secreted into serum-free medium over $2 \mathrm{~d}$ (see Fig. 4). We estimated the amounts of IGF binding proteins by densitometric scanning of autoradiographs from six independently performed ligand blots using conditioned AIB assay buffer and solubilized cells from three separate collections. Analysis of equivalent aliquots of conditioned AIB assay buffer and solubilized cells indicated that most of the binding protein present after a 3-h collection was secreted into AIB assay buffer. Overall, by densitometric scanning of autoradiographs, we estimated that 1.4-1.8 times more binding protein was secreted by CSC fibroblasts than by normal (GM5565) fibroblasts. Specifically, CSC fibroblasts secreted $1.3 \pm 0.16,1.8 \pm 0.34$, and $2.2 \pm 0.54$ (mean $\pm \mathrm{SD}$ ) times more of the $M_{r} 46,400 / 42,900$ doublet, the $M_{r} 32,000$ binding protein, and the $M_{r} 26,800$ binding protein, respectively, than normal fibroblasts.

Interestingly, as shown in Fig. 6, the electrophoretic profile

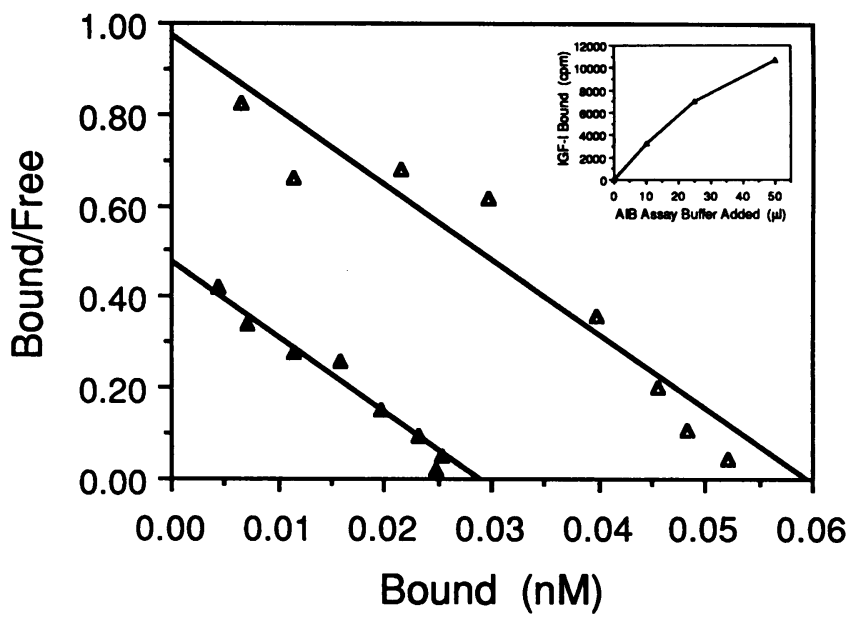

Figure 5. Scatchard plots of IGF-I binding to conditioned AIB assay buffer from normal and CSC fibroblasts. AIB assay buffer was collected from untreated GM5565 ( $\triangle$ ) and CSC ( $\triangle$ ) fibroblasts after a 3-h incubation at $37^{\circ} \mathrm{C}$. Cell counts were $3.24 \times 10^{6}$ cells/plate and 4.2 $\times 10^{6}$ cells/plate for GM5565 and CSC fibroblasts, respectively, in this experiment. IGF-I binding studies were performed as described in Methods, using $30 \mu \mathrm{l}$ of conditioned AIB assay buffer. The inset shows that the relationship of ${ }^{125}$ I-labeled IGF-I bound to the amount of conditioned AIB assay buffer (from CSC fibroblasts) in the assay is linear at $30 \mu$ l. Binding assays contained 11,900 or $23,700 \mathrm{cpm}$ $(0.015$ or $0.030 \mathrm{nM})$ of ${ }^{125}$ I-labeled IGF-I and $0-65.4 \mathrm{nM}$ of unlabeled IGF-I in a final volume of $250 \mu$ l. Each point represents the mean of duplicate determinations. Binding data were analyzed by LIGAND (22). $N$ was 0.0841 and 0.0978 for GM5565 and CSC fibroblasts, respectively, and nonspecific binding has been subtracted. The solid lines are computer-generated best fits for a one-site binding model. The dissociation constants for IGF-I binding to conditioned AIB assay buffer from GM5565 and CSC fibroblasts in this experiment were $0.060 \mathrm{nM}$ and $0.061 \mathrm{nM}$, respectively. 


\section{AIB assay buffer}

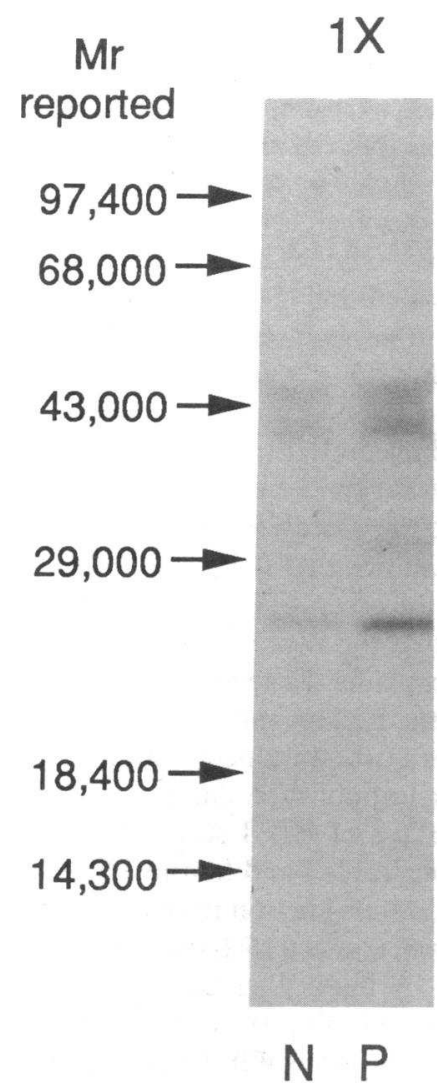

\section{solubilized cells}
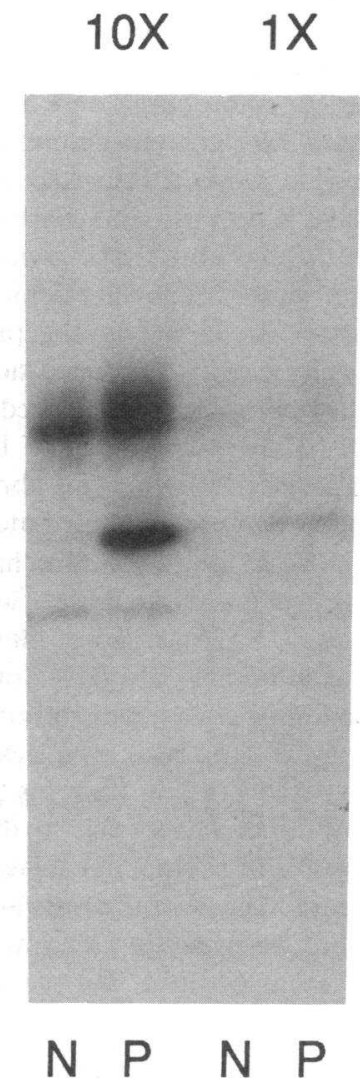

Figure 6. Ligand blot of secreted and cell-associated IGF binding proteins in normal and CSC fibroblasts. AIB assay buffer $(6.55 \mathrm{ml})$ was collected from untreated GM5565 $(N)$ and CSC $(P)$ fibroblasts after a 3-h incubation at $37^{\circ} \mathrm{C}$. The fibroblasts were then washed and solubilized in electrophoresis sample buffer $(500 \mu \mathrm{l})$. Equivalent aliquots of conditioned AIB assay buffer $(60 \mu \mathrm{l})$ and of solubilized cells $(4.5 \mu \mathrm{l})$ and a $10 \times$ aliquot of solubilized cells $(45 \mu \mathrm{l})$ were analyzed by ligand blotting, as described in Methods. In this autoradiograph, the densitometric signal of the $M_{r} 32,000$ binding protein in the $10 \times$ aliquot of solubilized CSC cells was 10.9 times higher than that in the $1 \times$ aliquot, confirming that the autoradiographic exposure gave densitometric signals in the linear range. The migration of prestained molecular weight standards is indicated.

of binding proteins that were cell-associated in CSC fibroblasts differed markedly from that of secreted binding proteins. Overall, by densitometric scanning of autoradiographs, we estimated that 1.8-2.9 times more binding protein was cell-associated in CSC fibroblasts than in normal (GM5565) fibroblasts. The major difference between normal and CSC fibroblasts was the striking amount of $M_{r} 32,000$ binding protein that was cell-associated in CSC fibroblasts. $1.4 \pm 0.28,10.0 \pm 1.41$, and $2.4 \pm 0.57$ (mean $\pm \mathrm{SD}$ ) times more of the $M_{r} 46,400 / 42,900$ doublet, the $M_{r} 32,000$ binding protein, and the $M_{r} 26,800$ binding protein, respectively, were cell-associated in CSC fibroblasts than in normal fibroblasts.

To demonstrate that the $M_{r} 32,000$ cell-associated IGF binding protein in solubilized CSC fibroblasts is on the cell surface, affinity cross-linking studies were performed, as shown in Fig. $7.12 .5 \%$ or $3-12.5 \%$ gradient acrylamide resolving gels were used in order to detect radioligand/binding protein complexes. In normal fibroblasts, ${ }^{125} \mathrm{I}$-labeled IGF-I was crosslinked predominantly to proteins that migrated under nonreducing conditions (Fig. $7 \mathrm{~A}$ ) as complexes with apparent $M_{r}$ $53,400 / 48,900$. These molecular weights are appropriate for complexes of cross-linked IGF-I $\left(M_{r} 7,649\right)$ with the $M_{r}$ $46,400 / 42,900$ doublet. In CSC fibroblasts, ${ }^{125}$ I-labeled IGF-I was cross-linked to an additional protein which migrated under nonreducing conditions (Fig. $7 A$ ) as a complex with apparent $M_{r} 41,800$. This molecular weight is appropriate for a complex of cross-linked IGF-I with the $M_{r} 32,000$ binding protein.
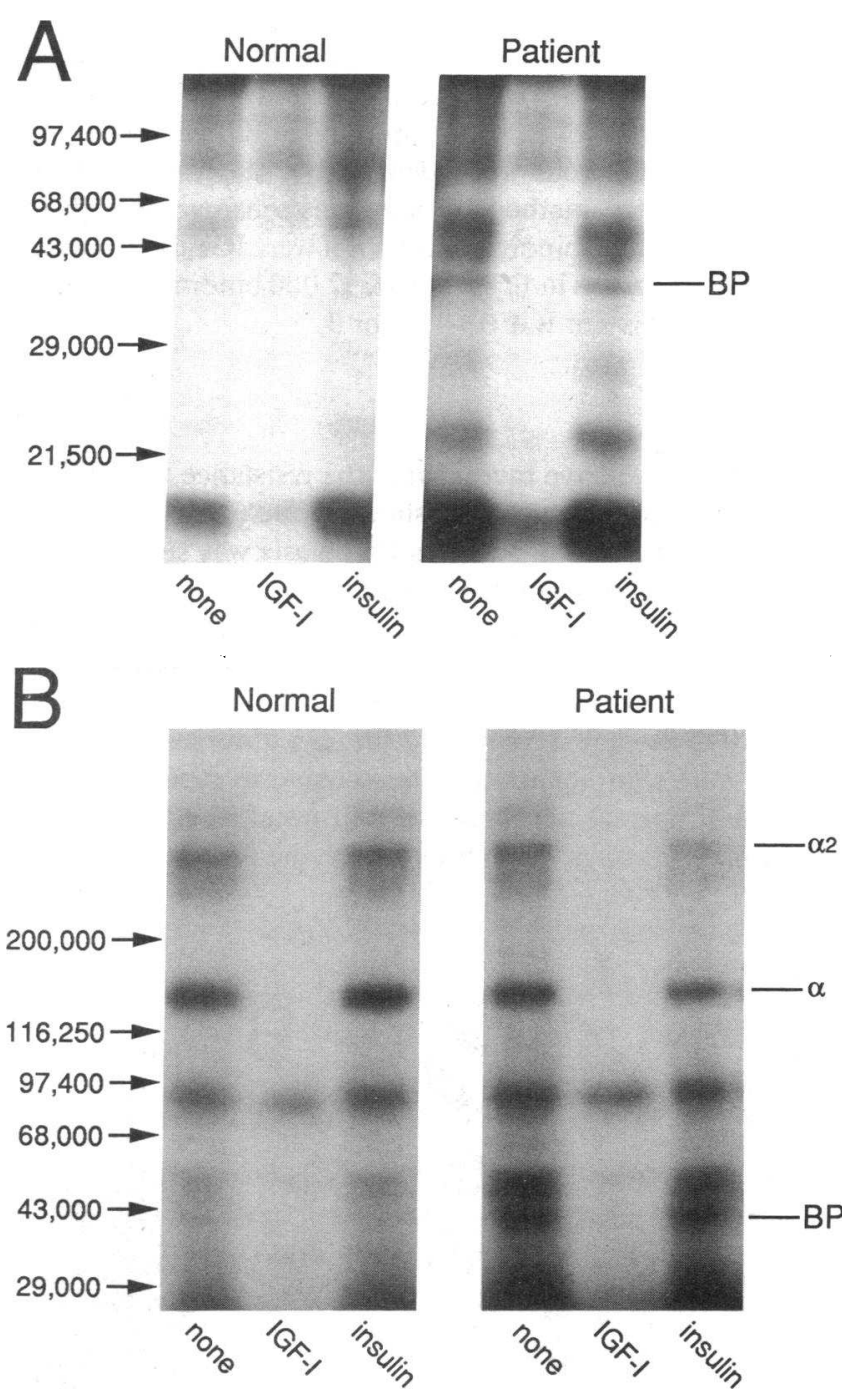

Figure 7. Affinity cross-linking analysis of cell-associated IGF binding proteins in normal and CSC fibroblasts. Day 8 GM5565 (4.64 $\times 10^{6}$ cells/plate) and CSC $\left(4.49 \times 10^{6}\right.$ cells/plate) fibroblasts were incubated at $4 \mathrm{~h}$ at $15^{\circ} \mathrm{C}$ with $0.2 \mathrm{nM}{ }^{125}$ I-labeled IGF-I in the absence or presence of $125 \mathrm{ng} / \mathrm{ml}$ of unlabeled IGF-I or unlabeled insulin, as indicated. Affinity cross-linking with $0.1 \mathrm{mM}$ disuccinimidyl suberate was performed as previously described (17) except that EDTA was omitted from the quenching buffer. $(A)$ The autoradiograph of the radioligand/binding protein complexes, analyzed by SDS-PAGE (12.5\% acrylamide resolving gel) under nonreducing conditions. $(B)$ The autoradiograph of the radioligand/binding protein and receptor complexes, analyzed by SDS-PAGE (3-12.5\% gradient acrylamide resolving gel) under reducing conditions. The migration of molecular weight standards is indicated. 
Under reducing conditions (Fig. 7 B), ${ }^{125} \mathrm{I}$-labeled IGF-I was cross-linked to this binding protein and to the $\alpha$ subunit (and the covalently cross-linked $\alpha_{2}$ dimer) of the IGF-I receptor. Cross-linking of ${ }^{125}$ I-labeled IGF-I was markedly inhibited by unlabeled IGF-I but not by unlabeled insulin.

Identification of the $M_{r}$ 32,000 IGF binding protein. We have performed studies to compare the characteristics of the $M_{r}$ 32,000 binding protein in CSC fibroblasts with the three distinct, well-characterized classes of IGF binding proteins (3). Ligand blot analysis demonstrated that the $M_{r} 32,000$ binding protein is similar in size to IGFBP-1 and different from IGFBP-2 (Fig. $8 \mathrm{~A}$ ) and IGFBP-3 (see Fig. 4). It is also different from the major binding protein in human CSF, which is similar in size to IGFBP-2. Nevertheless, the $M_{r} 32,000$ binding protein did not cross-react with an antibody against human IGFBP-1 (Fig. 8 B). Even small amounts of IGFBP-1 secreted by human HepG2 cells were identified in the Western blot, suggesting that the method we used was sensitive enough to detect the $M_{r} 32,000$ binding protein if it were IGFBP-1. Taken together, these results indicate the $M_{r} 32,000$ binding protein in CSC fibroblasts is not IGFBP-1, 2, or 3.

\section{Discussion}

In this report, we have investigated the resistance to IGF-I in fibroblasts from one child with short stature (6). The cause of IGF-I resistance in this patient's fibroblasts was suggested by experiments with an IGF-I variant, $\left[Q^{3}, A^{4}, Y^{15}, L^{16}\right] I G F-I$, which has a 600 -fold reduced affinity for IGF binding proteins (9). Binding of this IGF-I variant to normal fibroblasts and to the patient's fibroblasts was similar and was inhibited by $\alpha$ IR3 , a MAb to the IGF-I receptor. Although fibroblasts from the patient were significantly less responsive to stimulation by IGF-I than normal fibroblasts in AIB uptake and thymidine incorporation assays, their response to the IGF-I variant was normal. Taken together with affinity cross-linking studies, these results indicated that the IGF-I receptor in this patient's fibroblasts was structurally and functionally intact and suggested that IGF-I sensitivity was reduced by increased amounts of endogenous IGF binding proteins. To confirm this directly, secreted and cell-associated IGF-I binding proteins from this patient's fibroblasts were analyzed. IGF-I binding studies and ligand blot analysis demonstrated that the amount of binding protein secreted into AIB assay buffer by the patient's fibroblasts was approximately two times higher than that secreted by normal fibroblasts. Ligand blot analysis and affinity crosslinking studies further demonstrated that the amount of a cell surface $M_{r} 32,000$ binding protein was increased 10 -fold. These results support the conclusion that IGF-I sensitivity in this patient's fibroblasts is reduced by an abnormal production and/ or cell association of IGF binding proteins. It remains to be established whether this abnormality is present in other IGF-I target tissues and contributes to this child's short stature.

While binding studies have shown that secreted IGF binding proteins may interfere with the access of IGFs to cell receptors $(7,8,25)$, it is not likely that the twofold increase in secreted binding proteins alone explains the resistance to IGF-I action in our patient's fibroblasts. Reducing the assay volume from 500 to $250 \mu$ l, which causes a twofold concentration of the secreted binding proteins (our unpublished data), results in only a small increase in the $\mathrm{ED}_{50} \mathrm{~S}$ of IGF-I stimulated AIB uptake in normal fibroblasts (see Table I and footnote 2). It is more likely that the resistance to IGF-I action in our patient's fibroblasts results from interference with IGF-I-dependent activation of the IGF-I receptor by the cell surface $M_{r} 32,000$ binding protein. In competition binding studies, fibroblasts from the patient bound 2.9 times more IGF-I than normal (GM5565) fibroblasts but similar amounts of the IGF-I variant. In addition, a MAb to the IGF-I receptor blocked IGF-I binding to the patient's fibroblasts less potently than to normal
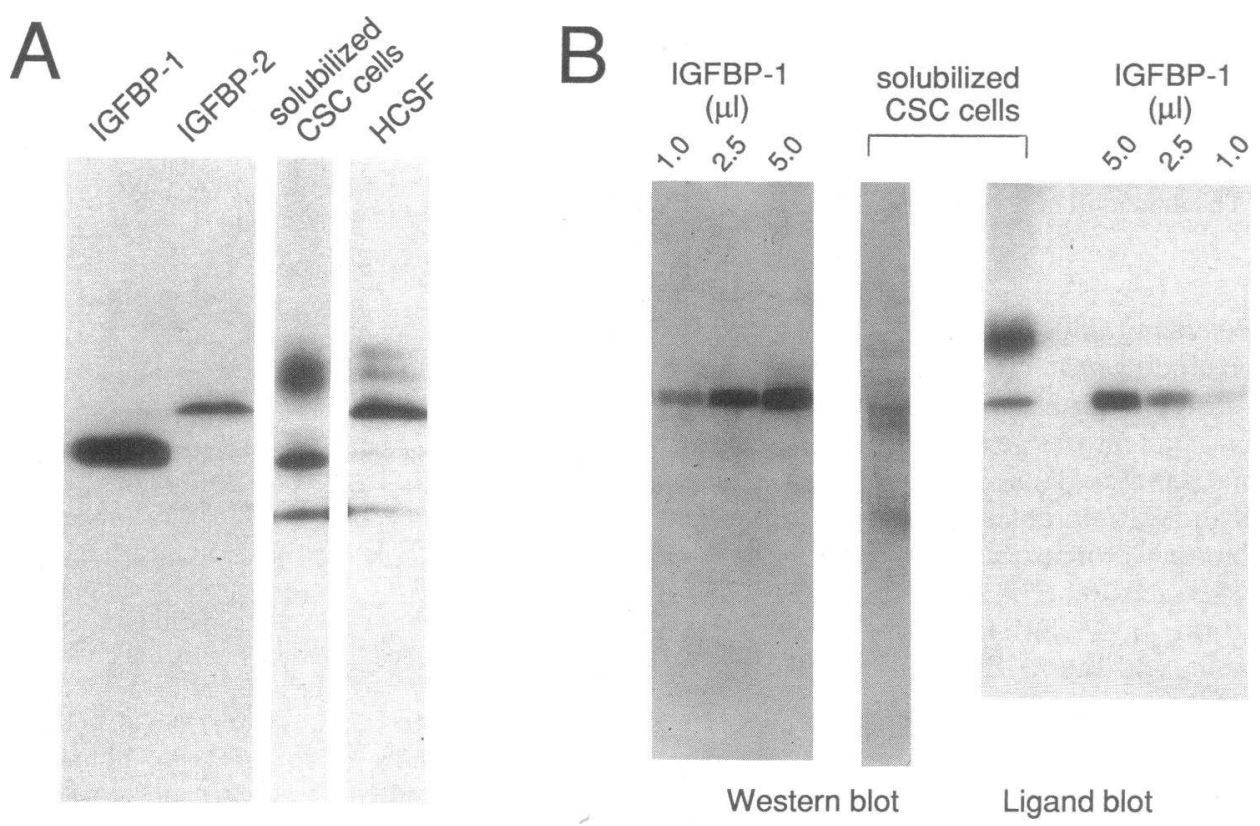

Figure 8. Ligand and Western blot comparison of the CSC fibroblast $M_{r} 32,000$ binding protein and IGFBP-1 and IGFBP-2. CSC fibroblasts were washed and solubilized in $500 \mu \mathrm{l}$ electrophoresis sample buffer. HepG2 and Jurkat cells were grown for $\sim 64 \mathrm{~h}$ in serum free-media that was collected and clarified by low speed centrifugation. $(A) \mathrm{Li}$ gand blot of a 10- $\mu$ l aliquot of conditioned medium from HepG2 cells, a 60- $\mu \mathrm{l}$ aliquot of conditioned medium from Jurkat cells, a 15- $\mu$ l aliquot of $10 \times$-concentrated human CSF ( $H C S F)$, and a 45- $\mu$ l aliquot of solubilized CSC cells. $(B)$ Western and ligand blot of solubilized CSC cells and IGFBP-1. Aliquots (1-5 $\mu l$, as indicated) of conditioned medium from HepG2 cells and a 90- $\mu$ l aliquot of solubilized CSC cells were analyzed by ligand blotting (right half of filter) and Western blotting (left half of filter), as described in

Methods. Complexes of IGFBP-1 and rabbit anti-human IGFBP-1 antibody were detected with alkaline phosphatase-conjugated goat antirabbit IgG. 
fibroblasts. Since binding studies were performed at $4^{\circ} \mathrm{C}$, a temperature at which no binding protein is secreted into the medium (our unpublished data), secreted binding proteins did not interfere with IGF-I binding to cell receptors in these studies. Ligand blot analysis confirmed that 1.8-2.9 times more binding protein was associated with the patient's fibroblasts than with normal (GM5565) fibroblasts and demonstrated that this increase resulted largely from a 10 -fold increase in the cell association of the $M_{r} 32,000$ binding protein. The mechanism by which the cell surface $M_{r} 32,000$ binding protein interferes with IGF-I action in the patient's fibroblasts remains to be determined.

The identity of the fibroblast $M_{r} 32,000$ binding protein is not clear. Both IGFBP-1 $(13,33,34)$ and IGFBP-2 $(14,35)$ contain an RGD sequence near their carboxyl termini which may interact with specific cell-surface receptors in the integrin superfamily (36). Hill et al. (32) reported that fibroblasts secrete a binding protein with apparent $M_{r} 30,000$ that reacts with an antibody raised against IGFBP-1 purified from human amniotic fluid. In contrast, Martin and Baxter (30) reported that no binding protein was detectable in fibroblast-conditioned medium by RIA or by immunoprecipitation of affinity crosslinked complexes using another antibody raised against human amniotic fluid IGFBP-1. Their results are supported by the recent observation by Conover et al. (31) that RNA isolated from fetal or postnatal human fibroblasts did not hybridize on Northern blot analysis with an IGFBP-1 cDNA probe from the HepG2 cell line. Since the nucleotide sequences of IGFBP-1 cDNAs from a human decidua library (33) and a human placenta library (34) and from a human HepG2 library (13) are nearly identical, these apparently conflicting results are not readily explained. It is possible that differences existed in the fibroblast lines used or in the specificities of the antibodies available in these studies. Alternatively, it is possible that the secretion of IGFBP-1 is developmentally regulated, since Hill et al. (32) reported that the ability of fibroblasts to secrete IGFBP-1 was related to cell density, being greatest in sparse cultures. The expression of IGFBP-2 in human fibroblasts has not been reported, but the mRNA expression of this binding protein in the rat has been shown to be highest in fetal tissues and greatly reduced in the corresponding adult tissues (35). Martin and Baxter (30) reported that a $\left({ }^{125}\right.$ I-labeled IGF-II cross-linked) human fibroblast binding protein similar in size to IGFBP-1 could be immunoprecipitated using an antibody against IGFBP-3. This antibody (and an antibody against IGFBP-2 [37]) have also been reported to cross-react with a binding protein in conditioned medium from the SV40-transformed human fibroblast line AG2804 (38). We compared the characteristics of the cell-associated $M_{r} 32,000$ binding protein in CSC fibroblasts with these well-characterized IGF binding proteins. The $M_{r} 32,000$ binding protein is similar in size to IGFBP-1, but it does not cross-react with an antibody against purified human amniotic fluid IGFBP-1. It is smaller than IGFBP-2. Finally, it does not appear to be analogous to the SV40-transformed human fibroblast binding protein since we have found that it is not detected by Western blot analysis or by immunoprecipitation of affinity cross-linked complexes using an antibody against IGFBP-3 (our unpublished data). Martin et al. (37) recently reported that the secretion of a human fibroblast binding protein doublet with apparent $M_{r} 29,000 / 31,000$ could be greatly enhanced by IGF-I and IGF-II; by Western blot analysis, this binding protein did not cross-react with anti- bodies against IGFBP-1, 2, and 3. Whether this secreted binding protein is analogous to the cell-associated $M_{r} 32,000$ binding protein in CSC fibroblasts remains to be determined.

The physiological relevance of cell surface binding proteins has not been clearly defined. DeMellow and Baxter (39) reported that coincubation of IGF-I with purified IGFBP-3 inhibited IGF-I-stimulated thymidine incorporation in human neonatal fibroblasts but that preincubation of fibroblasts with IGFBP-3 before adding IGF-I resulted in a potentiation of IGF-I action. The adherence of IGFBP-3 to the cell surface was not examined in these studies, although our study (see Fig. 7) and that of Clemmons et al. (8) suggest that a small amount of IGFBP-3 may adhere to the cell surface. Recent studies in human choriocarcinoma JEG-3 cells demonstrated that purified IGFBP-1 inhibited the maximal stimulation of AIB uptake by $10 \mathrm{ng} / \mathrm{ml} \mathrm{IGF-I} \mathrm{(40),} \mathrm{but}{ }^{125}$ I-labeled IGFBP-1 alone or complexed to IGF-I did not bind to the JEG-3 cell surface in these studies. In contrast, Elgin et al. (41) reported that purified IGFBP-1 potentiated IGF-I stimulated DNA synthesis in human, mouse embryo, and chick embryo fibroblasts and porcine aortic smooth muscle cells. Subsequent studies revealed two forms of this binding protein with different biologic actions (42). One form, designated peak B, enhanced IGF-I stimulation of $\left[{ }^{3} \mathrm{H}\right]$ thymidine incorporation into smooth muscle cell DNA, and a second form, peak $C$, prevented this response to peak $B$ and IGF-I. Peak B was shown to adhere to cell surfaces whereas peak $\mathrm{C}$ did not. Further elucidation of IGF binding protein production and the regulation thereof in CSC fibroblasts may provide important insights into the physiological role of cell surface binding proteins in IGF action.

\section{Acknowledgments}

We appreciate the advice and continuing support of Dr. Dennis $M$. Bier. We thank K. Thompson, D. Brown, and A. Shah for excellent technical assistance; D. Henke for preparation of the manuscript; and Drs. Steven Jacobs, David Clemmons, and Robert Baxter for provision of antibodies.

This work was supported in part by U.S. Public Health Service grant HD-20805 and by a grant from the Juvenile Diabetes Foundation (S. E. Tollefsen).

\section{References}

1. Daughaday, W. H., and P. Rotwein. 1989. Insulin-like growth factors I and II. Peptide, messenger ribonucleic acid and gene structures, serum, and tissue concentrations. Endocr. Rev. 10:68-91.

2. Ullrich, A., A. Gray, A. W. Tam, T. Yang-Feng, M. Tsubokawa, C. Collins, W. Henzel, T. Le Bon, S. Kathuria, E. Chen, S. Jacobs, U. Francke, J. Ramachandran, and Y. Fujita-Yamaguchi. 1986. Insulin-like growth factor I receptor primary structure: comparison with insulin receptor suggests structural determinants that define functional specificity. EMBO (Eur. Mol. Biol. Organ.) J. 5:2503-2512.

3. Ballard, F., R. Baxter, M. Binoux, D. Clemmons, S. Drop, K. Hall, R. Hintz, M. Rechler, E. Rutanen, and J. Schwander. 1990. Report on the nomenclature of the IGF binding proteins. J. Clin. Endocrinol. Metab. 70:817-818.

4. Baxter, R. C., and J. L. Martin. 1989. Binding proteins for the insulin-like growth factors: structure, regulation and function. Prog. Growth Factor Res. 1:49-68.

5. Bierich, J. R., H. Moeller, M. B. Ranke, and R. G. Rosenfeld. 1984. Pseudopituitary dwarfism due to resistance to somatomedin: a new syndrome. Eur. $J$. Pediatr. 142:186-188.

6. Heath-Monnig, E., H. J. Wohltmann, B. Mills-Dunlap, and W. H. Daughaday. 1987. Measurement of insulin-like growth factor I (IGF-I) responsiveness of fibroblasts of children with short stature: identification of a patient with IGF-I resistance. J. Clin. Endocrinol. Metab. 64:501-507.

7. De Vroede, M. A., L. Y.-H. Tseng, P. G. Katsoyannis, S. P. Nissley, and M. M. Rechler. 1986. Modulation of insulin-like growth factor I binding to hu- 
man fibroblast monolayer cultures by insulin-like growth factor carrier proteins released to the incubation media. J. Clin. Invest. 77:602-613.

8. Clemmons, D. R., R. G. Elgin, V. K. M. Han, S. J. Casella, A. J. D’Ercole and J. J. Van Wyk. 1986. Cultured fibroblast monolayers secrete a protein that alters the cellular binding of somatomedin-C/insulin-like growth factor I. J. Clin. Invest. 77:1548-1556.

9. Bayne, M. L., J. Applebaum, G. G. Chicchi, N. S. Hayes, B. G. Green, and M. A. Cascieri. 1988. Structural analogs of human insulin-like growth factor with reduced affinity for serum binding proteins and the type 2 insulin-like growth factor receptor. J. Biol. Chem. 263:6233-6239.

10. Tollefsen, S. E., K. Thompson, and D. J. Petersen. 1987. Separation of the high affinity insulin-like growth factor I receptor from low affinity binding sites by affinity chromatography. J. Biol. Chem. 262:16461-16469.

11. Kull, F. C., Jr., S. Jacobs, Y.-F. Su, M. E. Svoboda, J. J. Van Wyk, and P. Cuatrecasas. 1983. Monoclonal antibodies to receptors for insulin and somatomedin-C. J. Biol. Chem. 258:6561-6566.

12. Martin, J. L., and R. C. Baxter. 1985. Antibody against acid-stable insulinlike growth factor binding protein detects $150,000 \mathrm{~mol} \mathrm{wt}$ growth hormone-dependent complex in human plasma. J. Clin. Endocrinol. Metab. 61:799-801.

13. Lee, Y.-L., R. L. Hintz, P. M. James, P. D. K. Lee, J. E. Shively, and D. R Powell. 1988. Insulin-like growth factor (IGF) binding protein complementary deoxyribonucleic acid from human HEP G2 hepatoma cells: predicted protein sequence suggests an IGF binding domain different from those of the IGF-I and IGF-II receptors. Mol. Endocrinol. 2:404-411.

14. Binkert, C., J. Landwehr, J.-L. Mary, J. Schwander, and G. Heinrich 1989. Cloning, sequence analysis and expression of a cDNA encoding a nove insulin-like growth factor binding protein (IGFBP-2). EMBO (Eur. Mol. Biol. Organ.) J. 8:2497-2502.

15. Sasaoka, T., M. Kobayashi, Y. Takata, O. Ishibashi, M. Iwasaki, Y. Shigeta, K. Goji, and A. Hisatomi. 1988. Clarification of signaling pathways mediated by insulin and insulin-like growth factor I receptors in fibroblasts from patients with specific defect in insulin receptor. Diabetes. 37:1515-1523.

16. Heath-Monnig, E., and W. H. Daughaday. 1989. Sensitization of human fibroblasts to insulin-like growth factor I by serum deprivation and dexamethasone pretreatment. Endocr. Res. 15:303-322.

17. Tollefsen, S. E., J. L. Sadow, and P. Rotwein. 1989. Coordinate expression of insulin-like growth factor II and its receptor during muscle differentiation. Proc. Natl. Acad. Sci. USA. 86:1543-1547.

18. Laemmli, U. K. 1970. Cleavage of structural proteins during assembly of the head of bacteriophage T4. Nature (Lond.). 227:680-685.

19. Hossenlopp, P., D. Seurin, B. Segovia-Quinson, S. Hardouin, and M. Binoux. 1986. Analysis of serum insulin-like growth factor binding proteins using Western blotting: use of the method for titration of the binding proteins and competitive binding studies. Anal. Biochem. 154:138-143.

20. Towbin, H., T. Staehelin, and J. Gordon. 1979. Electrophoretic transfer of proteins from polyacrylamide gels to nitrocellulose sheets: procedure and some applications. Proc. Natl. Acad. Sci. USA. 76:4350-4354.

21. McCusker, R. H., and D. R. Clemmons. 1988. Insulin-like growth factor binding protein secretion by muscle cells: effect of cellular differentiation and proliferation. J. Cell. Physiol. 137:505-512.

22. Munson, P. J., and D. Rodbard. 1980. LIGAND: a versatile computerized approach for characterization of ligand-binding systems. Anal. Biochem. 107:220-239.

23. Van Obberghen-Schilling, E. E., M. M. Rechler, J. A. Romanus, A. B. Knight, S. P. Nissley, and R. E. Humbel. 1981. Receptors for insulin-like growth factor I are defective in fibroblasts cultured from a patient with Leprechaunism. $J$. Clin. Invest. 68:1356-1365

24. Kaplowitz, P. B. 1987. Glucocorticoids enhance somatomedin-C binding and stimulation of amino acid uptake in human fibroblasts. J. Clin. Endocrinol. Metab. 64:563-571.

25. Moses, A. C., P. Usher, N. Ikari, P. P. King, D. Tramontano, and J. S.
Flier. 1989. Multiple factors influence insulin-like growth factor-I binding to human skin fibroblasts. Endocrinology 125:867-875.

26. Flier, J. S., and A. C. Moses. 1985. Characterization of monoclonal antibodies to the IGF-I receptor that inhibit IGF-I binding to human cells. Biochem. Biophys. Res. Commun. 127:929-936.

27. Flier, J. S., P. Usher, and A. C. Moses. 1986. Monoclonal antibody to the type I insulin-like growth factor (IGF-I) receptor blocks IGF-I receptor-mediated DNA synthesis: clarification of the mitogenic mechanisms of IGF-I and insulin in human skin fibroblasts. Proc. Natl. Acad. Sci. USA. 83:664-668.

28. Tollefsen, S. E., R. Lajara, R. H. McCusker, D. R. Clemmons, and P. Rotwein. 1989. Insulin-like growth factors (IGF) in muscle development. Expression of IGF-I, the IGF-I receptor, and an IGF binding protein during myoblas differentiation. J. Biol. Chem. 264:13810-13817.

29. Martin, J. L., and R. C. Baxter. 1986. Insulin-like growth factor binding protein from human plasma. Purification and characterization. J. Biol. Chem. 261:8754-8760.

30. Martin, J. L., and R. C. Baxter. 1988. Insulin-like growth factor-binding proteins (IGF-BPs) produced by human skin fibroblasts: immunological relationship to other human IGF-BPs. Endocrinology. 123:1907-1915.

31. Conover, C. A., F. Liu, D. Powell, R. G. Rosenfeld, and R. L. Hintz. 1989. Insulin-like growth factor binding proteins from cultured human fibroblasts. Characterization and hormonal regulation. J. Clin. Invest. 83:852-859.

32. Hill, D. J., C. Camacho-Hubner, P. Rashid, A. J. Strain, and D. R. Clemmons. 1989. Insulin-like growth factor (IGF)-binding protein release by human fetal fibroblasts: dependency on cell density and IGF peptides. J. Endocrinol. 122:87-98.

33. Brewer, M. T., G. L. Stetler, C. H. Squires, R. C. Thompson, W. H. Busby, and D. R. Clemmons. 1988. Cloning, characterization, and expression of a human insulin-like growth factor binding protein. Biochem. Biophys. Res. Commun. 152:1289-1297.

34. Brinkman, A., C. Groffen, D. J. Kortleve, A. Geurts van Kessel, and S. L. S. Drop. 1988. Isolation and characterization of a cDNA encoding the low molecular weight insulin-like growth factor binding protein (IBP-1). EMBO(Eur Mol. Biol. Organ.) J. 7:2417-2423.

35. Brown, A. L., L. Chiariotti, C. C. Orlowski, T. Mehlman, W. H. Burgess, E. J. Ackerman, C. B. Bruni, and M. M. Rechler. 1989. Nucleotide sequence and expression of a cDNA clone encoding a fetal rat binding protein for insulin-like growth factors. J. Biol. Chem. 264:5148-5154.

36. Ruoslahti, E. 1988. Fibronectin and its receptors. Annu. Rev. Biochem. 57:375-413.

37. Martin, J. L., and R. C. Baxter. 1990. Production of an insulin-like growth factor (IGF)-inducible IGF-binding protein by human skin fibroblasts. Endocrinology. 127:781-788.

38. Martin, J. L., K. E. Willetts, and R. C. Baxter. 1990. Purification and properties of a novel insulin-like growth factor-II binding protein from transformed human fibroblasts. J. Biol. Chem. 265:4124-4130.

39. DeMellow, J. S. M., and R. C. Baxter. 1988. Growth hormone-dependent insulin-like growth factor (IGF) binding protein both inhibits and potentiates IGF-I-stimulated DNA synthesis in human skin fibroblasts. Biochem. Biophys. Res. Commun. 156:199-204.

40. Ritvos, O., T. Ranta, J. Jalkanen, A.-M. Suikkari, R. Voutilainen, H. Bohn, and E.-M. Rutanen. 1988. Insulin-like growth factor (IGF) binding protein from human decidua inhibits the binding and biological action of IGF-I in cultured choriocarcinoma cells. Endocrinology. 122:2150-2157.

41. Elgin, R. G., W. H. Busby, Jr., and D. R. Clemmons. 1987. An insulin-like growth factor (IGF) binding protein enhances the biologic response to IGF-I. Proc. Natl. Acad. Sci. USA. 84:3254-3258.

42. Busby, W. H., Jr., D. G. Klapper, and D. R. Clemmons. 1988. Purification of a 31,000-dalton insulin-like growth factor binding protein from human amniotic fluid. Isolation of two forms with different biologic actions. J. Biol. Chem 263:14203-14210 